\title{
On the relationship between corruption and migration: empirical evidence from a gravity model of migration
}

\author{
Marie Poprawe ${ }^{1}$
}

Received: 20 March 2014/Accepted: 27 March 2015/Published online: 3 April 2015

(C) Springer Science+Business Media New York 2015

\begin{abstract}
This paper shows the relationship between corruption and migration. In particular, countries with much corruption are shown to encourage emigration and discourage immigration because they provide worse and unpredictable economic conditions, more insecurity, and a lower quality of life. This hypothesis is confirmed empirically with a cross-sectional dataset with bilateral migration data covering 230 countries. Well-known implications of the gravity model are confirmed here: larger populations, a common language and a common border increase migration, while distance between two countries decreases migration. Furthermore, education, GDP per capita, inflation in the destination country, as well as corruption and education in the origin country can robustly explain migration. Corruption thus appears to be a push factor of migration.
\end{abstract}

Keywords Corruption · Migration · Gravity model

\section{JEL Classification F22 $\cdot$ D73}

\section{Introduction}

A vast amount of research has been conducted to determine how corruption affects the macroeconomic situation of an economy (Mauro 1995; Méon and Sekkat 2005; Dreher and Gassebner 2013). Another strand of research focuses on the factors that cause migration; differences in incomes in different economies frequently have been argued to be the main cause of migration Borjas (1989). This paper combines these two strands of literature by arguing that differences in corruption in different economies result in migration.

Studying the reasons for certain migration patterns is important to, as a next step, determine the policies required to shape migration patterns so as to limit the brain drain.

Marie Poprawe

marie.poprawe@gmail.com

$1 \quad$ ETH Zurich, 8092 Zurich, Switzerland 
The relevance of corruption as a driving force for migration is of interest in this paper. Similarly to the Tiebout-Tullock hypothesis, which argues that an individual migrates to a community which best represents his set of preferences (usually relating to public goods and/or taxation), it can be argued here that corruption is a form of taxation affecting an individual's preferences. As described in Cebula (2002), individuals compare bundles of public goods and taxation for different destinations and consequently make a migration decision. ${ }^{1}$ It can be argued that corruption is to be included in that bundle.

To determine whether people move from high-corruption countries to low-corruption countries, a gravity model for migration is evaluated using bilateral migration data for 230 countries for the year 2000 .

The political economy aspect of migration has been discussed in few works, such as Dreher et al. (2011), who present terrorism as a push factor of migration. Moore and Shellman (2004) and Radnitz (2006) analyze forced migration, while Bertocchi and Strozzi (2008) assess the relevance of institutional factors for nineteenth century international migration. The most closely related study is Dimant et al. (2013), who find that corruption affects net migration rates for a panel of 111 countries and 16 years. Also related is Cooray and Schneider (2014), who find heterogeneous effects for different educational skill groups of corruption on emigration.

This work uses bilateral migration data to test the hypothesis that corruption affects migration, in the sense that high corruption discourages immigration and encourages emigration in any given country. The logic behind this claim is as follows: Countries with high levels of corruption provide a less secure business environment, worse and insecure working conditions and encourage individuals to move to countries where less corruption is present, thereby avoiding the economic and social costs associated with corruption. We do so by adapting the model from Bertocchi and Strozzi (2008) to incorporate corruption as a form of costs that can be avoided by moving. The hypothesis is that, ceteris paribus, people will prefer living in countries with less corruption. A cross-sectional bilateral dataset for 230 countries $(52,900$ country-pairs) is used to provide evidence for this hypothesis. The paper furthermore shows that the results hold not only for perceived corruption but also for measures of experienced corruption.

The paper is structured as follows. Section 2 reviews the existing related literature and identifies the gaps in research that this paper seeks to fill. Section 3 outlines the theoretical motivation for this paper and describes the methodology. Section 4 describes the data. Section 5 provides the empirical results. Section 6 concludes.

\section{Literature review}

The effect of corruption on growth has frequently been analyzed. The origin of this debate can be found in Mauro (1995), who argues that corruption is caused mainly by trade restrictions, subsidies, price controls, multiple exchange rate practices and foreign exchange allocation schemes, as well as sociological factors, and shows that corruption hampers growth by reducing investment. Svendsen (2003) provides similar conclusions, arguing that less corrupt countries have high GDPs owing to efficient collective good provisions. Similarly, Ehrlich and Lui (1999) show that corruption has a negative effect on both growth and GDP per capita. Also, Djankov et al. (2006) show that the relationship

1 See Tiebout (1956) and Tullock (1971) for early discussions. See also Cebula and Zafoglis (1986), Cebula et al. (2014), and Goodspeed (1998) for applications of the Tiebout-Tullock hypothesis. 
between more business-friendly regulations and higher growth rates is consistently significant in various specifications of standard growth models. While Mauro (1995) argues that corruption decreases growth by decreasing investment, Méon and Sekkat (2005) find that corruption has a negative effect on growth independently of its impact on investment. On the other hand, Dreher and Gassebner (2013) find evidence that corruption can help increase growth especially in highly regulated economies, supporting the results of Méon and Weill (2010), who find that corruption can foster growth in the presence of inefficient institutions, while Aidt et al. (2008) find that corruption has no impact on growth if institutions are bad but has a negative impact in the presence of good institutions. Furthermore, Méndez and Sepúlveda (2006) find that the relationship between corruption and growth is non-monotonic and dependent on the political regime.

Stanton Russell (1995) gives a detailed overview of the five major approaches explaining migration (neoclassical macroeconomic theory, neoclassical microeconomic theory, new economics of migration, dual labor market theory, and world systems theory). Traditionally most research focuses on the neoclassical micro- and macroeconomic theories, such as Tunali (2000) or Gallin (2004), for example. However, some recent studies consider the political economy aspect of migration, a branch of research that is not found among the five major approaches in Stanton Russell (1995). For instance, Moore and Shellman (2004) focus on the push factors that cause people to flee their homes, what they refer to as forced migration. They show that violent behavior of the state or dissident actors, large numbers of armed attacks and riots, government terror, and human rights violations have a significant effect on the expected number of forced migrants, while GNP does not have an effect on the number of forced migrants. The authors summarise that "the push factor of violence drives the process" directly (p. 742). In contrast, Radnitz (2006), studying migration behavior within the former Soviet Union, finds that nationalism and political factors influence migration decisions only insofar as they affect people's material well-being and the economic environment. Bertocchi and Strozzi (2008) assess the relevance of institutional factors for nineteenth century international migration and find that better institutions are associated with higher migration rates. Good institutions in the New World represent a significant factor of attraction in their analysis.

Most closely related to this study is a paper by Dimant et al. (2013) who analyze the effect of corruption on net migration rates for a panel of 111 countries and three time periods at five-year intervals. They find that corruption is among the push factors of migration, especially concerning skilled migration. Furthermore, they find that skilled migration is less common in richer countries and that there is a positive effect of political instability on skilled migration. Cooray and Schneider (2014) find evidence that this relationship also holds for non-high-skilled workers. With the exception of Dimant et al. (2013) and Cooray and Schneider (2014), the effect of corruption on migration has been neglected in both theoretical and empirical research. This gap in the existing literature will be filled here. In particular, this paper tests the hypothesis that corruption affects migration, in the sense that high corruption discourages immigration and encourages emigration in any given country. Countries with high levels of corruption provide a less secure business environment and worse working conditions and encourage individuals to move to countries where less corruption is present. The main contribution of this paper is the utilization of bilateral migration data instead of net migration rates as this allows determining whether corruption is a push or a pull factor. With net migration rates, this distinction is not possible as it is unknown from where migrants come and to where they move. 


\section{The model}

\subsection{Basic setup}

Neoclassical migration theory views migrants as actors who decide to move on the basis of a cost-benefit calculation. The Tiebout-Tullock hypothesis argues that an individual migrates to a community which best represents his set of preferences-which in this setting incorporate corruption. Therefore, a model including corruption as a cost is shown here. ${ }^{2}$ Following Bertocchi and Strozzi (2008), a simple dynamic model with bequests is presented here. All individuals in the model are identical and have a choice between staying in their home country, $H$, or moving to a foreign country, $F$. Each individual in the model lives for one period and has a single child to whom he can leave a bequest. Preferences are given by

$$
u_{t}=(1-\theta) \log x_{t}+\theta \log b_{t+1},
$$

where $x_{t}$ is individual consumption, $b_{t+1}$ is the bequest left to the child, and $0<\theta<1$. The budget constraint is $x_{t}+b_{t+1} \leq y_{t}$ and, if it is satisfied, the solution is given by

$$
\begin{aligned}
x_{t} & =(1-\theta) y_{t} \\
b_{t+1} & =\theta y_{t} .
\end{aligned}
$$

Using these results, one finds that the indirect utility function is given by

$$
v_{t}=\log y_{t}+(1-\theta) \log (1-\theta)+\theta \log \theta .
$$

So, the level of utility of each individual depends directly on income $y_{t}$. Now, when making a decision whether to move or not, each individual compares his income in the home and foreign country, $y_{t}^{H}$ and $y_{t}^{F}$, respectively. In particular, the incomes in the two settings are given by:

$$
\begin{aligned}
\text { income in home country: } y_{t}^{H} & =w_{t}^{H}-\delta c_{t}^{H} \\
\text { income in foreign country: } y_{t}^{F} & =w_{t}^{F}-\delta c_{t}^{F}-c m,
\end{aligned}
$$

where $w_{t}^{H}$ is the wage at home while $w_{t}^{F}$ is the wage if the individual moves to the foreign country, $c_{t}^{H}$ and $c_{t}^{F}$ are the corruption levels in the home and foreign country, respectively, $\delta>0$, and $\mathrm{cm}$ is the cost of moving. Corruption has a negative effect on total income - one could think of this as bribes having to be paid, or as a tax [as in Aidt (2003)]. The cost of moving, $\mathrm{cm}$, contains any costs, such as financial costs of moving, language barriers or giving up a business in the home country. They rise with greater distance, and fall, for example, if the two countries have a common language, or if a large stock of foreigners of the same nationality is present in the country of destination. An individual will move to the foreign country if $y_{t}^{F}>y_{t}^{H}$. That is, he will move if

$$
\left(w_{t}^{F}-w_{t}^{H}\right)-\delta\left(c_{t}^{F}-c_{t}^{H}\right)-c m>0 .
$$

In other words, people move from $\mathrm{H}$ to $\mathrm{F}$ if the benefits of moving (in terms of higher wages and less corruption) exceed the costs of moving $(\mathrm{cm})$. The wage differential, $w_{t}^{F}-w_{t}^{H}$, is determined by, amongst others, differences in GDP, taxes, political stability,

\footnotetext{
${ }^{2}$ Alternatively one could use a utility function containing consumption in $t$ and $t+1$. The conclusion drawn from this would be the same, i.e., that indirect utility is an increasing function of income.
} 
economic freedom, inflation, government spending, the rule of law, education, and the legal system. That is, what matters are the differences between $i$ 's and $j$ 's attributes reflected in the wage differential and the differences in corruption, and also the $i$ - $j$-pairspecific attributes reflected in the costs of moving. Aggregating over all individuals, the net migration rate will be higher for countries with relatively high incomes and low corruption, and lower for countries with low incomes and high corruption.

\subsection{Econometric specification}

To determine the effect of corruption on migration in this bilateral setting, a gravity equation is estimated, along the lines of Anderson and van Wincoop (2003). The original

Table 1 Descriptive statistics for the main variables in the dataset

\begin{tabular}{llllll}
\hline Variable & $\mathrm{N}$ & Mean & SD & Min & Max \\
\hline Migration & 50,848 & $3,094.49$ & $48,267.06$ & 0 & $3,789,377$ \\
Corruption & 20,468 & 4.798 & 2.37 & 1.2 & 10 \\
GDP & 43,238 & 8.355 & 1.33 & 5.26 & 10.90 \\
Distance & 46,438 & 8.827 & 0.76 & 4.11 & 9.89 \\
Population & 33,578 & 8.711 & 1.68 & 4.14 & 13.77 \\
\% tert. educ. & 33,578 & 10.053 & 8.73 & 0.34 & 48.47 \\
Tax rate & 32,428 & 6.84 & 8.93 & 0 & 36.28 \\
Gov. & 43,238 & 12.626 & 9.09 & 1.69 & 56.05 \\
Inflation & 28,288 & 8.525 & 2.09 & 0 & 10 \\
Common language & 46,440 & 0.169 & 0.38 & 0 & 1 \\
Common colonizer & 46,438 & 0.118 & 0.32 & 0 & 1 \\
Common Currency & 46,438 & 0.013 & 0.11 & 0 & 1 \\
Common Border & 46,438 & 0.028 & 0.16 & 0 & 1 \\
Common Legal Origin & 46,228 & 0.289 & 0.45 & 0 & 1 \\
Legal sys. \& Prop.rights & 28,288 & 5.970 & 2.02 & 1.20 & 9.60 \\
Econ. Freedom & 28,288 & 6.469 & 0.99 & 4.00 & 8.82 \\
Pol. system & 36,338 & 2.898 & 6.57 & -10 & 10 \\
Political stability & 43,698 & -0.086 & 1.00 & -2.59 & 1.66 \\
Conflict $i$ \& $j$ & 40,018 & 0.292 & 0.46 & 0 & 1 \\
(Civil) war & 48,070 & 0.18 & 0.51 & 0 & 2 \\
Rule of Law & 46,228 & -0.029 & 1.00 & -2.31 & 1.94 \\
fractionalization & 34,729 & 0.550 & 0.27 & 0 & 1 \\
\hline Migran & & & & & \\
\hline
\end{tabular}

Migration: number of migrants from $i$ to $j$

Corruption Corruption Perception Index, GDP log per capita GDP, Distance log distance between $i$ and $j$, Population log population, \% tert. educ. percentage of population with tertiary education, Tax rate average personal income tax rate, Gov. government spending as a percentage of GDP, Inflation control of inflation, Common language dummy indicating whether $i$ and $j$ share a common language (spoken by at least $9 \%$ of the population), Common colonizer dummy indicating whether $i$ and $j$ had the same colonizer, Common Currency dummy indicating whether $i$ and $j$ share a common currency, Common border dummy indicating wether $i$ and $j$ share a common border, Common Legal Origin dummy indicating whether $i$ and $j$ share a common legal origin, Legal sys. \& Prop.rights legal system and property rights, Econ. freedom economic freedom, Pol. system polity score, Political stability political stability estimate, Conflict dummy indicating whether $i$ and $j$ are at war, (Civil) war, intensity of (civil) war, Rule of law rule of law, fractionalization fractionalization index 
gravity models of trade predict that trade flows between any two countries depend on their economic sizes and the distance between them. A similar concept is applied here, but instead of explaining trade patterns this paper explains migration patterns. While trade is a movement of goods, migration is a movement of labor; the two share many properties and migration gravity models make use of these similarities. Migration patterns have frequently been explained using variables that control for the geographical, cultural and economic distances between nations. In particular, just as in trade gravity models, it has been found that an greater distance reduces migration, while cultural proximity may lead to more migration. Higher incomes and larger populations have been found to increase migration flows.

The following equation is estimated:

$$
M_{i, j}=\delta_{i} X_{i}+\delta_{j} X_{j}+\delta_{i, j} X_{i, j}+\varepsilon_{i, j},
$$

where the subscripts $i$ and $j$ refer to the origin and destination country, respectively. The dependent variable $M_{i, j}$ refers to migration from $i$ to $j$, the $X_{i}$ are origin-specific, the $X_{j}$ are destination-specific, and the $X_{i, j}$ are country-pair specific variables, while $\varepsilon_{i, j}$ is an error term. The goal is to estimate $\delta_{i}, \delta_{j}$ and $\delta_{i, j}$, with a particular emphasis on the coefficients of Corruption $_{i}$ and Corruption $_{j}$.

To avoid detecting only spurious effects of corruption on migration, a number of confounding controls with a simultaneous effect on both corruption and migration are considered. In particular, per capita income, population size, regime type, trade openness, education, institutional attributes, and political stability are accounted for, following Dimant et al. (2013). These variables are all contained in $X_{i}$ and $X_{j}$. Trade gravity models frequently include country-pair-specific variables (contained in $X_{i, j}$ ) such as the distance, common language, common border, common colonizer, common legal origin, and common currency. Migration gravity models have adopted the use of these variables, for example in Karemera et al. (2000), and are therefore used here too.

The dependent variable $M$ is a count variable with a large number of zeroes. In particular, around 23,000 of the 50,000 country-pairs have zero migration flows between them. One solution would be to use a Poisson model in order to estimate Eq. 2; however, the Poisson model has been criticized because of its implicit assumption that the variance of the dependent variable equals its mean, an assumption not satisfied by the data-Table 1 shows that Migration has a mean of 3094 and a standard deviation of 48,267. ${ }^{3}$ A solution to this problem is to estimate a different parametric model that is more dispersed than the Poisson. A more appropriate model is the negative binomial model because it relaxes the Poisson assumption of equality of the conditional mean and variance functions Greene (2008).

\section{Data}

Bilateral migration data from the World Bank's Global Migration Database Özden et al. (2011) are available for 230 countries at 10-year-intervals. The database provides information on international bilateral migrant stocks which serve as the dependent variable in the analysis. The year 2000 is chosen for the analysis because data availability is highest at

\footnotetext{
3 The maximum value reached is $3,789,377$, a lot further from the mean than two standard deviations. The observation responsible for this (the country-pair USA-Mexico) is clearly an outlier and is therefore removed from now on.
} 
that date. The main explanatory variable is the Corruption Perception Index by Transparency International. The index ranks countries by their perceived levels of corruption, as determined by expert assessments and opinion surveys. The indicator ranges from 0 to 10 , with higher scores signifying lower corruption. In the regressions, one would therefore expect a positive coefficient, implying that high-corruption countries (with low scores) tend to have lower net migration rates (consisting of high emigration and/or low immigration), on average. Though this three-dimensional relationship is difficult to display graphically, Fig. 1 shows the relationship between corruption in $i$ and $j$ as well as migration flows from $i$ to $j$. The large number of zero migrants between many country pairs becomes apparent in this graph. It can be observed that most migration occurs for low values of the Corruption Perception Index in $i$ (high corruption) and high values of the Corruption Perception Index in $j$ (low corruption). That is, people appear to move from high-corruption to low-corruption countries most often. Considerable migration likewise occurs from low-corruption countries to other low-corruption countries. ${ }^{4}$ This graph gives a first indication that there may in fact be a relationship between corruption and migration.

A number of control variables are included, taken mostly from Dimant et al. (2013), Cooray and Schneider (2014), and Karemera et al. (2000). Specifically, (socio-)economic development in the origin and destination countries are accounted for. GDP, openness, government spending, and and educational levels control for the level of development of the sending and receiving countries. High levels of socio-economic development likely will be a pull factor. Data on GDP per capita, trade openness, and government spending as a percentage of total GDP come from the Penn World Table (Heston et al. 2011). Data on typical gravity model variables, such as the distance between origin and destination countries measured as the linear distance between the two countries' closest borders, a common language, a common border, and a common currency are included to account for geographic and cultural proximity and come from the CEPII Gravity Database. Variables on educational attainment come from Barro and Lee (2013). Lederman et al. (2005) show that institutions affect corruption and Borjas (1987) shows that institutions also affect migration - to capture institutions and the political environment, the political and legal system, fractionalization, economic freedom, control of inflation, the size of government, political rights, and the polity index are included. Data on the political system (parliamentary versus presidential; plurality or proportional representation) and a fractionalization index come from the Database on Political Institutions (World Bank). Data on civil war come from the Uppsala Conflict Database Program(UCDP). Data on economic freedom, the legal system and property rights, and the relative size of government ${ }^{5}$ come from the Economic Freedom of the World project of the Fraser Institute. Data on political rights and civil liberties come from Freedom House. Polity data come from the Polity IV project. Higher values of these variables indicate better economic and social conditions. Data on Control of Inflation, Political Stability, and Rule of Law are from the World Governance Indicators published by the World Bank. Following Kleven et al. (2013) one must account for taxation, which has been shown to induce migration. Data on taxes, specifically on the average tax rate for an income equivalent to GDP per capita, come from the Andrew Young School World Tax Indicators. Descriptive statistics of the variables are displayed in Table 1.

\footnotetext{
4 This type of migration occurs between wealthy countries; for example, between EU countries and the US, or within the EU.

5 The latter two being sub-indices of the overall economic freedom index.
} 


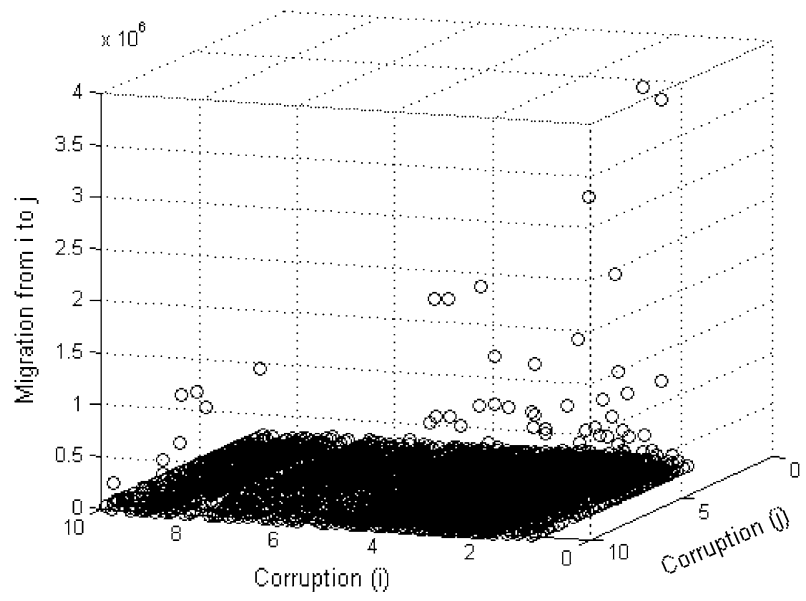

High values of the Corruption index imply low corruption.

Fig. $13 \mathrm{D}$ scatterplot of corruption in $i$ and $j$ and migration between $i$ and $j$. High values of the Corruption index imply low corruption

To comment briefly on the expected signs of the coefficients, one expects wealthier, freer, stabler, and more open economies to attract more migrants on average. On the other hand, worse economic and socio-economic conditions in the origin country will be migration push factors. Following the basic implications of the gravity model and the results from Karemera et al. (2000), distance between any two countries should reduce migration between them, while common socio-economic and cultural attributes should increase migration between them. ${ }^{6}$

\section{Results}

\subsection{Main results}

The main results of negative binomial regressions of migration on corruption are displayed in Table 2. All standard errors reported are heteroscedasticity-robust. All regressions include log per capita GDP in the home country, $G D P(i)$, and in the destination country, $G D P(j)$, the $\log$ population in $i$ and $j$, as well as Corruption $(i)$ and Corruption $(j)$. Corruption has the expected effect on migration; that is, if corruption in the origin country decreases (so the corruption index increases), fewer people move from $i$ to $j$, on average. In particular, if the corruption index in $i$ increases by 1 (corruption falls) then migration from $i$ to $j$ falls by about $30 \%$. Similarly, if corruption in the destination country decreases, more people move to the destination country, on average. This finding also remains after the

\footnotetext{
${ }^{6}$ It is beyond the scope of this paper to study the spatial patterns of migration and corruption and thus the paper abstracts from possible spillover effects as described by Becker et al. (2009). However, if one were to take into account the spatial aspect of migration decisions, the estimated coefficient of Corruption (i) is likely a lower bound.
} 
Table 2 Main results

\begin{tabular}{|c|c|c|c|c|}
\hline & (1) & (2) & (3) & (4) \\
\hline GDP (i) & $0.258 * * *(6.96)$ & $0.183 * * *(3.72)$ & $0.384 * * *(10.55)$ & $0.222 * *(2.21)$ \\
\hline GDP (j) & $0.0333(0.98)$ & $0.393 * * *(8.68)$ & $0.166 * * *(4.94)$ & $0.496 * * *(8.16)$ \\
\hline Corruption (i) & $\begin{array}{r}-0.321 * * * \\
(-14.35)\end{array}$ & $\begin{array}{r}-0.284 * * * \\
(-11.83)\end{array}$ & $-0.253 * * *(-9.31)$ & $-0.219 * * *(-2.87)$ \\
\hline Corruption (j) & $0.0442 * * *(24.55)$ & $0.0297 * * *(12.43)$ & $0.102 * * *(21.04)$ & $0.140 * * *(3.22)$ \\
\hline Distance & $\begin{array}{r}-1.671 * * * \\
(-42.41)\end{array}$ & $\begin{array}{r}-1.632 * * * \\
(-39.48)\end{array}$ & $\begin{array}{r}-1.596 * * * \\
(-43.39)\end{array}$ & $\begin{array}{r}-1.051 * * * \\
(-11.48)\end{array}$ \\
\hline Population (i) & $0.844 * * *(37.72)$ & $0.846 * * *(36.69)$ & $0.768 * * *(34.79)$ & $0.700 * * *(13.56)$ \\
\hline Population (j) & $1.059 * * *(44.67)$ & $0.965 * * *(37.83)$ & $0.996 * * *(44.17)$ & $0.772 * * *(15.69)$ \\
\hline$\%$ tert. educ. (i) & & $0.00927 * *(2.47)$ & & $-0.0119(-1.43)$ \\
\hline$\%$ tert. educ. (j) & & $0.0584 * * *(13.72)$ & & $0.0420 * * *(4.12)$ \\
\hline Tax rate (i) & & $-0.00281(-0.68)$ & & 0.0103 \\
\hline Tax rate $(\mathrm{j})$ & & $\begin{array}{l}-0.0134 * * * \\
(-3.14)\end{array}$ & & $\begin{array}{l}-0.0249 * * * \\
(-2.71)\end{array}$ \\
\hline \multirow[t]{2}{*}{$\begin{array}{l}\text { Common } \\
\text { language }\end{array}$} & & & $1.695 * * *$ & $1.405 * * *$ \\
\hline & & & (20.39) & $(8.77)$ \\
\hline Pol. system (i) & & & & $-0.109(-1.16)$ \\
\hline Pol. system (j) & & & & $0.178 *(1.77)$ \\
\hline $\begin{array}{l}\text { Legal sys. \& } \\
\text { Prop. } \\
\text { rights (i) }\end{array}$ & & & & $0.034 * * *(3.40)$ \\
\hline $\begin{array}{l}\text { Legal sys. \& } \\
\text { Prop. } \\
\text { rights (j) }\end{array}$ & & & & $0.141 * *(2.09)$ \\
\hline Econ. freedom (i) & & & & $0.193(1.56)$ \\
\hline Econ. freedom (j) & & & & $0.0475(0.45)$ \\
\hline Gov./GDP (i) & & & & $0.0182(0.81)$ \\
\hline Gov./GDP (j) & & & & $-0.0277(-1.51)$ \\
\hline $\begin{array}{l}\text { Common } \\
\text { colonizer }\end{array}$ & & & & $0.769 * *(2.30)$ \\
\hline $\begin{array}{l}\text { Common Legal } \\
\text { Origin }\end{array}$ & & & & $0.582 * * *(4.22)$ \\
\hline (Civil) war (i) & & & & $0.189(1.19)$ \\
\hline (Civil) war (j) & & & & $-0.339 * *(-2.52)$ \\
\hline Common Border & & & & $1.259 * * *(3.44)$ \\
\hline$N$ & 6640 & 6318 & 6640 & 5548 \\
\hline
\end{tabular}

Negative binomial regressions with heteroscedasticity-robust standard errors; dependent variable: Migration in 2000. Variables with neither (i) nor (j) are country-pair-specific. $t$ statistics in parentheses

$i$ origin country, $j$ destination country

$* p<0.10, * * p<0.05, * * * p<0.01$

inclusion of several control variables. The coefficients on corruption in the origin country $i$ are all negative and statistically significant, while those on corruption in the destination country $j$ are positive and significant, though smaller in magnitude. The coefficients for the 
control variables have the expected sign and almost all are significant. ${ }^{7}$ All specifications include the distance between $i$ and $j$ and their populations, and the results indicate that larger populations are correlated with more migration, while a greater distance is associated with less migration. Column (2) includes the tertiary education rate and average income tax rate in both $i$ and $j$. A higher tertiary education rate in the destination country significantly increases migrant flows from $i$ to $j .{ }^{8}$ Destination countries with higher education levels are presumably more attractive to immigrants because of higher wages and good employment prospects, for example for the immigrants' offspring. Taxes in the origin country have no statistically significant effect, while a high tax rate in destination country $j$ significantly discourages migration. Of course, low taxes then encourage immigration, a phenomenon described by Kleven et al. (2013), who find strong evidence of tax-induced migration. Column (3) shows that a common language (spoken by at least $9 \%$ of the population) shared by $i$ and $j$ greatly increases migration flows between them. Column (4) controls for all variables included in columns (2) and (3) and additionally for the political system, the legal system and property rights, economic freedom, government spending as a percentage of GDP, a common colonizer dummy, a common legal origin dummy, the presence of (civil) war, and a common border dummy. In this specification, government spending and economic freedom have no statistically significant effect on migration. A good legal and political system and well-established property rights in $j$ encourage movement from $i$ to $j$, while civil war in the destination country discourages movement from $i$ to $j$. A common colonizer increases migration, as does a common legal origin and a common border. These results align with the theoretical implications of the migration gravity model and empirical results in previous studies, particularly Karemera et al. (2000). The effect of corruption on migration behavior remains statistically significant across the four specifications presented.

\subsection{Robustness checks}

Several modifications of the preferred specification were estimated to ensure consistency and robustness of the results. In particular, an Extreme Bounds Analysis, used here to test the stability of the coefficients and their significance, is presented in Sect. 5.2.1. Furthermore, different models are tested in Sect. 5.2.3, and the main variable of interest, the Corruption Perception Index by Transparency International, is exchanged for alternative corruption measures and measures of experienced corruption in Sects. 5.2.2 and 5.2.4. In addition, a unilateral dataset of net migration rates is used to confirm the results presented above in Sect. 5.2.5. Overall, the robustness checks performed confirm the main results.

\subsubsection{Extreme bounds analysis as a robustness check}

The main interest of this paper lies primarily with the coefficients of Corruption $(i)$ and Corruption $(j)$, and the purpose of this section is to check whether these coefficients are robust to the addition and removal of other explanatory variables, both in terms of

\footnotetext{
7 For some control variables for the origin country the estimated coefficient sometimes contradicts the hypothesized sign (for example, $G D P(i)$ ) - this effect can be attributed to large volumes of North-North migration in comparison to total migrant flows. In regressions excluding North-North country-pairs, the coefficients are negative.

8 The effect of education in the origin country is positive and statistically significant in this specification, but negative in column (4). Its overall effect is ambiguous.
} 
magnitude and in terms of statistical significance. For that purpose, this section uses the Extreme Bounds Analysis (EBA) methodology initially presented in Leamer (1983) and later modified in Sala-i-Martin (1997). According to the EBA, an explanatory variable is "robust" only if the estimated coefficient remains statistically significant and maintains the same sign in all regressions run with different sets of control variables Serra (2006).

In the growth literature, the use of the extreme bounds analysis (EBA) methodology can frequently be found as a robustness check, for example in Levine and Renelt (1992).

To ensure that corruption robustly can explain net migration, this section applies the EBA methodology to the current setting. In the equation

$$
M=\alpha X+\beta C+\gamma Z+u
$$

$M$ is some variable of interest (here: migration) that one wishes to explain by the righthand side variables, $X$ is a vector of standard economic explanatory variables that previously have been found to robustly affect the dependent variable, $C$ is an explanatory variable whose robustness needs to be tested (here: corruption), and $Z$ is a vector of potential additional explanatory variables. The extreme bound test as in Leamer (1983) for variable $C$ says that if the lower extreme bound of $\beta$ (the lowest value of $\beta$ minus two standard deviations) and the upper extreme bound for $\beta$ (the highest value for $\beta$ plus two standard deviations) have the same sign, then variable $C$ is robustly related to variable $M$.

As Sala-i-Martin (1997) argues, Leamer's robustness criterion is very strong and restrictive, and few variables pass it in practice. Instead, Sala-i-Martin proposes to analyze the entire distribution of the estimates of $\beta$. His criterion is that if the average $90 \%$ confidence interval of a regression coefficient's distribution does not include zero the variable is correlated with the dependent variable; that is, more than 0.9 of the cumulative distribution function of the coefficient $(\mathrm{CDF}(0))$ must be on one side of zero. ${ }^{9}$ This approach has more frequently been applied because it allows some variables to pass but is still restrictive enough to determine which variables are fragile [see, e.g., Sturm et al. (2005), Gassebner et al. (2013)].

Here Sala-i-Martin's approach is used to test whether corruption and migration are robustly related. While Sala-i-Martin proposes to use a $90 \%$ confidence interval and a weighted cumulative distribution function, a $95 \%$ confidence interval and a nonweighted cumulative distribution function will be used as the criterion here, as in Sturm and de Haan (2005). ${ }^{10}$ Negative binomial regressions with five variables out of a pool of 29 variables were run, and logarithmized GDP per capita and the logarithmized populations both in the origin and destination country are included in every regression (so that each regression contains nine explanatory variables, five in which are varied). That is, around 118,000 regressions are run. The results are shown in Table 3. Displayed are the minimum achieved $\beta$ minus two standard deviations, the maximum achieved $\beta$ plus two standard deviations, the average $\beta$, the average standard error, the percentage of significant coefficients, and $\mathrm{CDF}(0)$. The ten variables above the horizontal line in the table are robust, while those below the line are not. The EBA results displayed in Table 3 clearly

\footnotetext{
9 Zero divides the area under the density in two. $\mathrm{CDF}(0)$ from now on refers to the larger of the two areas under the density function, either above or below zero.

10 The varying number of observations in the regressions in consequence of missing observations in some of the variables implies that using weights proportional to the integrated likelihood as a goodness-of-fit measure may not be a good indicator of the probability that a model is the true model, as explained in Sturm and de Haan (2005). The reason for using the criterion that $\operatorname{CDF}(0)>0.95$ is that $\operatorname{CDF}(0)$ will always be between 0.5 and 1; and using $\operatorname{CDF}(0)>0.95$ as Sala-i-Martin (1997) therefore seems too low.
} 
Table 3 Extreme Bounds Analysis

\begin{tabular}{|c|c|c|c|c|c|c|}
\hline & $\operatorname{Min} \beta$ & $\operatorname{Max} \beta$ & Avg. $\beta$ & Avg. s.e. & $\%$ sign. & $\mathrm{CDF}(0)$ \\
\hline Common border & 3.14 & 4.26 & 3.62 & 0.29 & 100 & 100 \\
\hline$\%$ tert. educ. (j) & 0.02 & 0.16 & 0.08 & 0.01 & 99.99 & 100.00 \\
\hline Population (j) & 0.04 & 1.17 & 0.71 & 0.03 & 99.78 & 100.00 \\
\hline Distance & -2.47 & 0.02 & -1.68 & 0.05 & 97.80 & 99.99 \\
\hline Population (i) & -0.13 & 0.93 & 0.66 & 0.03 & 98.65 & 99.90 \\
\hline GDP (j) & -0.41 & 2.12 & 0.66 & 0.06 & 96.99 & 99.43 \\
\hline Inflation (j) & -0.61 & 0.11 & -0.16 & 0.03 & 93.99 & 98.14 \\
\hline Common language & -0.81 & 2.92 & 1.40 & 0.10 & 91.37 & 97.75 \\
\hline$\%$ tert. educ. (i) & -0.03 & 0.13 & 0.03 & 0.01 & 86.07 & 97.18 \\
\hline Corruption (i) & -1.31 & 0.30 & -0.31 & 0.04 & 91.34 & 95.61 \\
\hline Legal sys.\& Prop.rights (j) & -0.54 & 1.28 & 0.32 & 0.04 & 89.31 & 94.18 \\
\hline (Civil) war (i) & -0.044 & 0.57 & 0.23 & 0.06 & 77.14 & 94.17 \\
\hline (Civil) war (j) & -0.37 & 0.26 & -0.07 & 0.05 & 60.32 & 93.23 \\
\hline Gov. (j) & -0.12 & 0.20 & -0.05 & 0.01 & 88.20 & 91.03 \\
\hline Political stability (j) & -2.03 & 1.18 & -0.57 & 0.08 & 85.08 & 89.78 \\
\hline Tax rate $(\mathrm{j})$ & -0.004 & 0.03 & 0.02 & 0.00 & 79.81 & 87.72 \\
\hline Political stability (i) & -1.84 & 1.08 & -0.53 & 0.08 & 90.10 & 87.72 \\
\hline Common currency & -2.79 & 3.89 & 1.48 & 0.34 & 79.81 & 85.44 \\
\hline fractionalization (i) & -1.85 & 4.48 & 0.77 & 0.22 & 76.08 & 83.18 \\
\hline Tax rate (i) & -0.001 & 0.034 & 0.016 & 0.00 & 74.28 & 81.30 \\
\hline Pol. system (i) & -1.28 & 0.73 & 0.07 & 0.04 & 85.35 & 77.34 \\
\hline Econ. freedom (i) & -1.36 & 0.91 & -0.20 & 0.07 & 75.64 & 75.71 \\
\hline fractionalization (j) & -3.63 & 4.69 & 0.62 & 0.22 & 74.03 & 75.21 \\
\hline Gov. (i) & -0.16 & 0.21 & -0.03 & 0.01 & 78.13 & 75.16 \\
\hline Conflict & -1.49 & 1.18 & -0.20 & 0.28 & 15.76 & 66.10 \\
\hline GDP (i) & -0.95 & 1.63 & -0.08 & 0.06 & 81.60 & 62.09 \\
\hline Econ. freedom (j) & -1.57 & 1.33 & 0.05 & 0.08 & 74.32 & 62.01 \\
\hline Rule of law (j) & -3.57 & 1.97 & -0.01 & 0.08 & 80.03 & 61.91 \\
\hline Inflation (i) & -0.60 & 0.27 & -0.05 & 0.03 & 60.05 & 61.15 \\
\hline Legal sys.\& Prop.rights (i) & -0.81 & 0.79 & 0.03 & 0.05 & 69.56 & 57.51 \\
\hline Pol. system (j) & -1.04 & 0.92 & 0.00 & 0.05 & 64.88 & 56.43 \\
\hline Rule of law (i) & -2.65 & 1.52 & -0.14 & 0.09 & 77.62 & 55.35 \\
\hline Corruption (j) & -1.26 & 0.91 & -0.01 & 0.04 & 75.60 & 50.60 \\
\hline
\end{tabular}

GDP $(i), G D P(j)$, Population $(i)$ and Population $(j)$ are included in every regression. Variables are ordered by $\operatorname{CDF}(0)$

$i$ origin country, $j$ destination country

show that most variables in the dataset can be considered as either push or pull factors; only the percentages of tertiary education and the populations in $i$ and $j$ are both push and pull factors.

GDP per capita in the destination country is a pull factor, while corruption in the origin country is a push factor. High GDP in the destination country attracts larger inflows of people, while high corruption in the origin country causes outflows. The average 
coefficients of the robust variables have the expected sign. ${ }^{11}$ In particular, countries with high education attract people, as do wealthy countries. A common language and a common border both increase the likelihood of migration, as does a shorter distance between the origin and destination country. On the other hand, the legal system, government spending, political stability, a common currency, the degree of fractionalization, taxes, the political system, economic freedom, conflict and civil war, the rule of law, inflation, and corruption in the destination country do not pass the robustness criterion-their coefficients are unstable to the addition of further control variables.

\subsubsection{Different measures of corruption as a robustness check}

Several measures of corruption are available and have been used in the recent literature. In addition to the Corruption Perception Index used so far, the Heritage Foundation provides a Freedom from Corruption indicator, ${ }^{12}$ and the World Bank publishes the Control of Corruption index. ${ }^{13}$ As a robustness check, both the corruption measure by the Heritage Foundation and that by the World Bank were used in place of the Corruption Perception Index by Transparency International. ${ }^{14}$ Table 4 presents regressions with the three different measures of corruption as explanatory variables [Columns (1)-(3)]. To ease comparability, Column (1) shows a regression with all regressors that have been found to be robustly related to migration in Table 3's EBA, and uses the Corruption Perception Index published by Transparency International. Column (2) estimates the same specification but uses the Freedom from Corruption measure published by the Heritage Foundation. Column (3) in turn uses the World Bank's Control of Corruption index. The results in terms of significance and magnitude do not differ from the analysis involving Transparency International's measure of corruption.

\subsubsection{Different specifications as a robustness check}

The negative binomial estimation technique has been criticized because its estimates depend on the choice of unit of the dependent variable (Bosquet and Boulhol 2010). Therefore, as an additional robustness check, a Poisson Pseudo-Maximum-Likelihood (PPML) regression with heteroscedasticity-robust standard errors [as in Santos Silva and Tenreyro (2006)] was run. While the magnitude of its coefficient changes, corruption in the origin country remains a significant explanatory variable, as Column (4) of Table 4 indicates.

\subsubsection{Perceived corruption versus experienced corruption}

The use of indices of perceived corruption has been criticized in the past-notably by Jahedi and Méndez (2014), Donchev and Ujhelyi (2014), and Treisman (2007)—because perceived corruption may not equal actual, experienced corruption. ${ }^{15}$ In order to ensure

\footnotetext{
11 With the exception of $\%$ tertiary education (i) - the sign of the coefficient can again be attributed to large North-North migration.

12 Its coverage in terms of countries is slightly larger as it relies heavily on the data published by Transparency International but fills any gaps with additional data.

13 It relies on 31 individual data sources and measures corruption in the public as well as private sector.

14 To facilitate comparability the indicators have been rescaled so that they range from 0 to 10 , with higher scores signifying lower corruption.

15 Although especially for receiving countries what matters to immigrants is the perceived level of corruption, about which immigrants are likely to hear.
} 
Table 4 Robustness checks: dfferent corruption measures and different estimation methods

\begin{tabular}{|c|c|c|c|c|c|}
\hline & (1) & (2) & (3) & (4) & $(5)$ \\
\hline Corruption (i) & $\begin{array}{c}-0.0254 * * \\
(-2.07)\end{array}$ & $\begin{array}{r}-0.045 * * \\
(-5.08)\end{array}$ & $\begin{array}{c}-0.0906 * * * \\
(-5.08)\end{array}$ & $\begin{array}{c}-0.185 * * * \\
(-2.66)\end{array}$ & $\begin{array}{c}-0.0384 * * \\
(-2.44)\end{array}$ \\
\hline Corruption (j) & $\begin{array}{r}0.319 * * * \\
(15.07)\end{array}$ & $\begin{array}{r}0.293 * * * \\
(15.07)\end{array}$ & $\begin{array}{r}0.288 * * * \\
(17.67)\end{array}$ & $0.133 *(1.66)$ & $0.175 * * *(3.83)$ \\
\hline GDP (i) & $\begin{array}{r}0.379 * * * \\
(10.05)\end{array}$ & $\begin{array}{r}0.381 * * * \\
(10.21)\end{array}$ & $\begin{array}{c}0.0904 * * * \\
(2.96)\end{array}$ & $0.269 *(1.72)$ & $0.271 * * *(3.60)$ \\
\hline GDP (j) & $0.329 * * *(8.08)$ & $0.322 * * *(7.99)$ & $0.247 * * *(9.03)$ & $0.439 *(1.82)$ & $\begin{array}{r}0.778 * * * \\
(10.04)\end{array}$ \\
\hline Distance & $\begin{array}{r}-1.443 * * * \\
(-45.33)\end{array}$ & $\begin{array}{r}-1.534 * * * \\
(-47.31)\end{array}$ & $-1.993 * * *$ & $\begin{array}{c}-1.058 * * * \\
(-8.59)\end{array}$ & $\begin{array}{r}-2.126 * * * \\
(-29.08)\end{array}$ \\
\hline $\begin{array}{l}\% \text { tert. educ } \\
\text { (i) }\end{array}$ & $0.00114(0.34)$ & $0.0029(0.83)$ & $\begin{array}{c}0.0132 * * * \\
(4.48)\end{array}$ & $0.0111(0.68)$ & $\begin{array}{c}-0.0200^{* * *} \\
(-2.44)\end{array}$ \\
\hline $\begin{array}{l}\% \text { tert. educ } \\
\text { (j) }\end{array}$ & $\begin{array}{c}0.0421 * * * \\
(11.02)\end{array}$ & $\begin{array}{c}0.0613 * * * \\
(13.52)\end{array}$ & $\begin{array}{c}0.0711 * * * \\
(20.90)\end{array}$ & $\begin{array}{c}0.0395 * * \\
(2.47)\end{array}$ & $\begin{array}{r}0.106^{* * * *} \\
(10.10)\end{array}$ \\
\hline Population (i) & $\begin{array}{r}0.942 * * * \\
(42.14)\end{array}$ & $\begin{array}{r}0.852 * * * \\
(39.82)\end{array}$ & $\begin{array}{r}0.809 * * * \\
(60.19)\end{array}$ & $\begin{array}{c}0.697 * * * \\
(9.65)\end{array}$ & $0.243 * * *(2.79)$ \\
\hline Population (j) & $\begin{array}{r}0.839 * * * \\
(39.28)\end{array}$ & $\begin{array}{r}0.799 * * * \\
(36.23)\end{array}$ & $\begin{array}{r}0.880 * * * \\
(63.62)\end{array}$ & $\begin{array}{r}0.621 * * * \\
(10.86)\end{array}$ & $0.580 * * *(6.60)$ \\
\hline $\begin{array}{l}\text { Common } \\
\text { language }\end{array}$ & $\begin{array}{r}1.806^{* * * *} \\
(22.23)\end{array}$ & $\begin{array}{r}1.559 * * * \\
(24.29)\end{array}$ & $\begin{array}{r}1.453 * * * \\
(25.60)\end{array}$ & $\begin{array}{c}1.056 * * * \\
(5.31)\end{array}$ & $\begin{array}{r}2.459 * * * \\
(13.99)\end{array}$ \\
\hline Inflation (i) & $\begin{array}{c}-0.0347 * * \\
(-2.47)\end{array}$ & $\begin{array}{c}-0.0352 * * \\
(-2.56)\end{array}$ & $\begin{array}{c}-0.0968 * * * \\
(-9.99)\end{array}$ & $\begin{array}{c}-0.0808 * * \\
(-2.15)\end{array}$ & $\begin{array}{c}-0.0991 * * * \\
(-2.98)\end{array}$ \\
\hline Inflation (j) & $\begin{array}{c}-0.103 * * * \\
(-6.67)\end{array}$ & $\begin{array}{c}-0.092 * * * \\
(-7.11)\end{array}$ & $\begin{array}{c}-0.0378 * * * \\
(-3.60)\end{array}$ & $\begin{array}{c}-0.132 * * * \\
(-4.78)\end{array}$ & $\begin{array}{c}-0.0966 * * * \\
(-2.81)\end{array}$ \\
\hline $\begin{array}{c}\text { Common } \\
\text { Border }\end{array}$ & $1.880 * * *(5.87)$ & $1.880 * * *(5.87)$ & $\begin{array}{r}2.725^{* * * *} \\
(10.83)\end{array}$ & $\begin{array}{c}2.023^{* * *} * \\
(2.68)\end{array}$ & $2.445 * * *(9.57)$ \\
\hline$N$ & 5850 & 5680 & 6230 & & 5104 \\
\hline Corruption data & TI & Heritage Fdn & World & 3ank & BPI \\
\hline Estimation & NB & NB & NB & & NB \\
\hline Time period & 2000 & 2000 & 2000 & & 2010 \\
\hline
\end{tabular}

Columns (1), (2), (3), and (5) use different corruption measures in otherwise identical specifications (negative binomial regressions with heteroscedasticity-robust standard errors). Column (4) presents a Poisson-Pseudo-Maximum Likelihood regression with heteroscedasticity-robust standard errors. Column (5) uses the Bribe Payers Index and migration data for 2010 in a negative binomial regression with heteroscedasticity-robust standard errors. $t$ statistics in parentheses

$* p<0.10, * * p<0.05, * * * p<0.01$

that the effect of corruption on migration is not driven solely by perceptions, Column (5) of Table 4 shows a regression using a measure of experienced corruption from the Global Corruption Barometer published by Transparency International. Corruption is measured by the percentage of people who have paid a bribe in the past 12 months. ${ }^{16}$ The results are very similar to those obtained from regressions with various perceived-corruption-indices.

\footnotetext{
16 These data are converted to a scale between 0 and 10 and reversed so that high values imply low levels of experienced corruption. Because a worldwide index of actual corruption has become available only recently, Column (5) shows a regression for the year 2010. The World Bank bilateral migration database provides data at 10-year intervals, the next available year being 2010. All control variables were collected for the year 2010 also, and all other data sources are the same as for the year 2000.
} 


\subsubsection{Unilateral net migration rates as a robustness check}

The main contribution of this paper is the use of bilateral migration data to determine the effect that corruption has on migration behavior. The disadvantage of this approach is that, owing to limited data availability, a panel analysis is not possible-time series information is available only for net migration. The dataset used in this robustness check consists of net migration rates for 38 economies, corruption, several wealth measures, labor market conditions, and other macroeconomic variables available annually for a 16 -year period. ${ }^{17}$ The reasons for this robustness check are (i) to increase comparability to the existing literature, in particular Dimant et al. (2013), (ii) to extend the time series dimension presented Dimant et al. (2013) (who use data at five-year intervals) to enable an analysis with an annual time series dimension, and (iii) to confirm the observed relationship from the cross-sectional dataset above for data with an annual time-series dimension.

Data on net migration are combined from the OECD International Migration Database and Eurostat databases. ${ }^{18}$ Data on GDP per capita, government spending as a percentage of GDP, GDP growth, populations and a trade openness index are from the Penn World Table. Data on public spending per capita and on demographics are from the OECD.

Table 5 shows some regression results when corruption (ICRG) is used as an explanatory variable to explain net migration behavior. Country-fixed-effects regressions are run, and standard errors are heteroscedasticity-robust. The advantage of this approach is that the estimated coefficients allow a direct interpretation for policy implications as they show which within-country changes can result in changes in net migration. Column 1 shows that the coefficient of Corruption is positive and significant. This supports the hypothesis stated above: Countries with a higher corruption index (i.e., lower actual corruption) have a higher net migration rate on average. That is, more people enter and/or fewer people leave a country with low corruption. In particular, if the corruption index increases by 1 (meaning that corruption decreases), the net migration rate increases by 0.4 percentage points. Column 2 includes GDP per capita, openness, and government spending, Column 3 includes public expenditure and GDP growth as controls, while Column 4 includes demographic attributes. The effect of corruption on net migration remains statistically significant across all specifications. Overall, these results are in line with Dimant et al. (2013), and Cooray and Schneider (2014), although the magnitude of the coefficient of corruption is larger here. ${ }^{19}$ While Dimant et al. (2013) find a significant effect of corruption only for skilled migration and not for all types of migration, a highly significant effect for all types of migration is found here. The findings presented here thus align with the observations made by Cooray and Schneider (2014).

Overall, the robustness checks presented here confirm the main results presented in Sect. 5.1. Across various specifications and datasets we find a significant effect of corruption on migration.

\footnotetext{
17 The 38 countries are: Austria, Australia, Belgium, Bulgaria, Canada, Croatia, Cyprus, Czech Republic, Denmark, Estonia, Finland, France, Germany, Greece, Hungary, Ireland, Italy, Japan, Latvia, Lithuania, Luxembourg, Malta, Mexico, New Zealand, Norway, Poland, Portugal, Romania, Slovak Republic, Slovenia, Korea, Spain, Sweden, Switzerland, The Netherlands, Turkey, United Kingdom and the United States. Years range from 1993 to 2008.

18 The datacode in Eurostat is tsdde230.

19 These differences may be because of an extension of the time period covered, and because of a different sample.
} 
Table 5 Country-fixed effects regressions of net migration on corruption and other variables

\begin{tabular}{|c|c|c|c|c|c|}
\hline & (1) & (2) & (3) & (4) & \\
\hline Corruption & $0.407 * *(2.02)$ & $0.902 * * *(3.63)$ & $0.542 * *(2.53)$ & $0.608 * * *(2.87)$ & \\
\hline GDP & & $8.122 * * *(8.17)$ & $7.567 * * *(4.80)$ & $5.439 * * *(6.18)$ & \\
\hline Open & & $-0.0176(-1.46)$ & & $-0.0104(-0.95)$ & \\
\hline Gov & & $0.292 * * *(2.84)$ & & & \\
\hline GDPgrowth & & & $-0.0167(-0.28)$ & $-0.0180(-0.32)$ & \\
\hline Pub.exp.pc & & & $-1.207(-0.91)$ & & \\
\hline$\%$ young & & & & $-0.445^{* *}(-2.54)$ & \\
\hline$\%$ old & & & & $-0.0363(-0.19)$ & \\
\hline$N$ & 496 & 492 & 368 & 385 & \\
\hline Countries & & 37 & 37 & 29 & 30 \\
\hline$R^{2}$ & 0.01 & 0.15 & 0.21 & 0.21 & \\
\hline
\end{tabular}

Standard errors are heteroscedasticity-robust. Constants are included but not displayed here. $t$ statistics in parentheses

$* p<0.10, * * p<0.05, * * * p<0.01$

\section{Conclusion}

The main finding of this paper is that corruption in the origin country $i$ leads to emigration from $i$. This result is robust to the inclusion and removal of other control variables, and holds also for differing specifications, other corruption measures, and a second dataset. The implication is that corruption is mostly a push factor of migration.

The results presented in Sect. 5.1 generally are in line with the existing literature and with the hypotheses proposed. Some conclusions that may be drawn from the regressions presented in Table 2 are well-known in the gravity-model-literature. In particular, a common border, a common language, a common colonizer, and a common legal origin all increase the likelihood of migration. Greater distance, on the other hand, decreases the likelihood of migration from $i$ to $j$. These results are in line with both the implications of the gravity model and previous empirical studies (e.g., Letouzé et al. (2009)). The EBA shows that education in $i$ and $j$, population in $i$ and $j$, the distance between $i$ and $j$, a common language, a common border, GDP per capita and inflation in $j$ and corruption in $i$ are robust to the inclusion and removal of other control variables. Work by Dreher et al. (2011) has shown that political instability is a push factor of migration. While this variable does not quite pass the EBA robustness criterion, the findings presented here mostly support this finding.

As argued above, corruption is mainly a push factor of migration. That is, high corruption forces people to move away to countries with lower levels of corruption. The decision to emigrate is affected strongly by the disincentive of corruption at home. This main finding is consistent with the hypothesis that corruption lowers the returns to labor and consequently enters negatively in the cost-benefit calculation of prospective migrants. Corruption has been argued to harm, inter alia, the wealth of an economy, its growth level, and the level of investment. Cumbersome and dishonest bureaucracies slow down the speed of doing business and burden workers with additional costs, both in terms of money and time. Apart from the well-known effects of corruption on output and growth, corruption forces part of the labor force out of the country, thereby lowering output even 
further. Therefore, corruption has a severe impact on the economy along several dimensions; anti-corruption measures may therefore discourage workers from emigrating.

Acknowledgments I thank two anonymous referees as well as the editor in chief for helpful comments and suggestions. I also thank participants at the 2012 World Congress of the Public Choice Societies (Miami), the 2012 Beyond Basic Questions Workshop (Schiermonnikoog), and the 2011 KOF Brown Bag Seminar (Zurich) for their valuable feedback.

\section{References}

Aidt, T. S. (2003). Economic analysis of corruption: A survey. Economic Journal, 113(491), 632-652.

Aidt, T. S., Dutta, J., \& Sena, V. (2008). Governance regimes, corruption and growth: Theory and evidence. Journal of Comparative Economics, 36, 195-220.

Anderson, J. E., \& van Wincoop, E. (2003). Gravity with gravitas: A solution to the border puzzle. American Economic Review, 93(1), 170-192.

Barro, R. J., \& Lee, J. W. (2013). A new data set of educational attainment in the world, 1950-2010. Journal of Development Economics, 104, 184-198.

Becker, S. O., Egger, P. H., \& Seidel, T. (2009). Common political culture: Evidence on regional corruption contagion. European Journal of Political Economy, 25, 300-310.

Bertocchi, G., \& Strozzi, C. (2008). International migration and the role of institutions. Public Choice, 137, $81-102$.

Borjas, G. (1989). Economic theory and international migration. International Migration Review, 23(3), $457-485$.

Borjas, G. J. (1987). Self-selection and the earnings of immigrants. American Economic Review, 77(4), 531-553.

Bosquet, C. \& Boulhol, H. (2010). Scale-dependence of the negative binomial pseudo-maximum likelihood estimator, Documents de travail du Centre d'Economie de la Sorbonne 10092, Université PanthéonSorbonne (Paris 1), Centre d'Economie de la Sorbonne.

Cebula, R. J. (2002). Migration and the Tiebout-Tullock hypothesis revisited. The Review of Regional Studies, 32(1), 87-96.

Cebula, R. J., \& Zafoglis, M. Z. (1986). A note on the Tiebout-Tullock hypthesis: The period 1975-1980. Public Choice, 48, 65-69.

Cebula, R. J., Nair-Reichert, U., \& Coombs, C. K. (2014). Total state in-migration rates and public policy in the United States: A comparative analysis of the Great Recession and the pre- and post-Great Recession years. Regional Studies, Regional Science, 1(1), 102-115.

Cooray, A. V., \& Schneider, F. (2014). Does corruption promote emigration? An empirical examination, Discussion Paper 8094, IZA.

Dimant, E., Krieger, T., \& Meierrieks, D. (2013). The effect of corruption on migration, 1985-2000. Applied Economics Letters, 20, 1270-1274.

Djankov, S., McLiesh, C., \& Ramalho, R. M. (2006). Regulation and growth. Economics Letters, 92(3), 395-401.

Donchev, D., \& Ujhelyi, G. (2014). What do corruption indices measure? Economics \& Politics, 26(2), 309-331.

Dreher, A., \& Gassebner, M. (2013). Greasing the wheels? The impact of regulations and corruption on firm entry. Public Choice, 155, 413-432.

Dreher, A., Krieger, T., \& Meierrieks, D. (2011). Hit and (they will) run: The impact of terrorism on migration. Economics Letters, 113(1), 42-46.

Ehrlich, I., \& Lui, F. (1999). Bureaucratic corruption and endogenous economic growth. Journal of Political Economy, 107(6), 270-293.

Gallin, J. (2004). Net migration and state labour market dynamics. Journal of Labour Economics, 1, 1-21.

Gassebner, M., Lamla, M., \& Vreeland, J. R. (2013). Extreme bounds of democracy. Journal of Conflict Resolution, 57(2), 171-197.

Goodspeed, T. J. (1998). On the importance of public choice in migration models. Economics Letters, 59, 373-379.

Greene, W. H. (2008). Econometric analysis. Boston: Pearson.

Heston, A., Summers, R., \& Aten, B. (2011). Penn world table version 7.0, dataset. Center for International Comparisons of Production, Income and Prices at the University of Pennsylvania. 
Jahedi, S., \& Méndez, F. (2014). On the advantages and disadvantages of subjective measures. Journal of Economic Behavior \& Organization, 98, 97-114.

Karemera, D., Oguledo, V. I., \& Davis, B. (2000). A gravity model analysis of international migration to North America. Applied Economics, 32(13), 1745-1755.

Kleven, H. J., Landais, C., \& Saez, E. (2013). Taxation and international migration of superstars: Evidence from the European football market. American Economic Review, 103(5), 1892-1924.

Leamer, E. (1983). Let's take the con out of econometrics. American Economic Review, 73, 31-43.

Lederman, D., Loayza, N. V., \& Soares, R. R. (2005). Accountability and corruption: Political institutions matter. Economics \& Politics, 17(1), 1-35.

Letouzé, E., Purser, M., Rodriguez, F., \& Cummins, M. (2009). Revisiting the migration-development nexus: A gravity model approach, Discussion Paper 19227, MPRA.

Levine, R., \& Renelt, D. (1992). A senstivity analysis of cross-country growth regressions. American Economic Review, 82(4), 942-963.

Mauro, P. (1995). Corruption and growth. Quarterly Journal of Economics, 110(3), 681-712.

Méndez, F., \& Sepúlveda, F. (2006). Corruption, growth and political regimes: Cross country evidence. European Journal of Political Economy, 22(1), 82-98.

Méon, P.-G., \& Sekkat, K. (2005). Does corruption grease or sand the wheels of growth? Public Choice, 122, 69-97.

Méon, P.-G., \& Weill, L. (2010). Is corruption an efficient grease? World Development, 38, $244-259$.

Moore, W., \& Shellman, S. (2004). Fear of prosecution: Forced migration, 1952-1995. Journal of Conflict Resolution, 48(5), 723-745.

Özden, C., Parsons, C. R., Schiff, M., \& Walmsley, T. L. (2011). Where on earth is everybody? The evolution of global bilateral migration 1960-2000. World Bank Economic Review, 25(1), 12-56.

Radnitz, S. (2006). Weighing the political and economic motivations for migration in post-Soviet space: The case of Uzbekistan. Europe-Asia Studies, 58(5), 653-677.

Sala-i-Martin, X. (1997). I just ran two million regressions. American Economic Review, 87(2), 178-183.

Santos Silva, J. M. C., \& Tenreyro, S. (2006). The log of gravity. Review of Economics and Statistics, 88, 641-658.

Serra, D. (2006). Empirical determinants of corruption: A sensitivity analysis. Public Choice, 126, $225-256$.

Stanton Russell, S. (1995). International migration: implications for the World Bank, Working Papers 54, HRO.

Sturm, J., \& de Haan, J. (2005). Determinants of long-term growth: New results applying robust estimation and extreme bounds analysis. Empirical Economics, 30, 597-617.

Sturm, J.-E., Berger, H., \& de Haan, J. (2005). Which variables explain decisions on IMF credit? An extreme bounds analysis. Economics \& Politics, 17(2), 177-213.

Svendsen, G. T. (2003). Social capital, corruption and economic growth: Eastern and Western Europe, Working Papers 03-21, University of Aarhus, Aarhus School of Business, Department of Economics.

Tiebout, C. (1956). A pure theory of local expenditures. Journal of Political Economy, 64(1), 416-424.

Treisman, D. (2007). What have we learned about the causes of corruption from ten years of cross-national empirical research? Annual Review of Political Science, 10, 211-244.

Tullock, G. (1971). Public decisions as public goods. Journal of Political Economy, 79(4), 913-918.

Tunali, I. (2000). Rationality of migration. International Economic Review, 41(4), 893-920. 